ORIGINAL ARTICLE / ARTIGO ORIGINAL

\title{
Bullying in Brazilian school children: analysis of the National Adolescent School-based Health Survey (PeNSE 2012)
}

\author{
Bullying em escolares brasileiros: análise da \\ Pesquisa Nacional de Saúde do Escolar (PeNSE 2012)
}

\author{
Deborah Carvalho Malta',"l, Denise Lopes Porto', Claudio Dutra Crespo'"', \\ Marta Maria Alves Silva', Silvania Suely Caribé de Andrade', Flavia Carvalho Malta de Mello'v, \\ Rosane Monteirov, Marta Angélica lossi Silvalv
}

\begin{abstract}
Objective: To describe the victimization and bullying practice in Brazilian school children, according to data from the National Adolescent School-based Health Survey and to compare the surveys from 2009 and 2012. Methods: This is a cross-sectional study with univariate and multivariate analyzes of the following variables: to have been treated badly by colleagues, to have been bullied and to have bullied other children. The following independent variables were analyzed: age, sex, race/color, type of school, maternal education. Prevalence rates were compared between the editions of 2009 and 2012 of the survey. Results: Of all the adolescents analyzed, $27.5 \%$ have not been treated well by peers at school, with greater frequency among boys $(\mathrm{OR}=1.50)$, at the age of 15 years $(\mathrm{OR}=1.29)$ and $16(\mathrm{OR}=1.41)$, public school students $(\mathrm{OR}=2.08)$, black $(\mathrm{OR}=1.18)$ and whose mothers had less education; $7.2 \%$ reported having been bullied, with a greater chance in younger students (13 years old), male $(\mathrm{OR}=1.26)$, black $(\mathrm{OR}=1.15)$ and indigenous $(\mathrm{OR}=1.16)$ and whose mothers had less education; $20.8 \%$ reported to have bullied other children, with a greater chance for older students, at the age of $14(\mathrm{OR}=1.08)$ and 15 years $(\mathrm{OR}=1.18)$, male $(\mathrm{OR}=1.87)$, black $(\mathrm{OR}=1.14)$ and yellow $(\mathrm{OR}=1.15)$, children of mothers with higher education, private school students. There was an increase of bullying in the Brazilian capitals, from 5.4 to $6.8 \%$, between 2009 and 2012. Discussion: The occurrence of bullying reveals that the Brazilian school context is also becoming a space of reproduction of violence, in which it is crucial to act intersectorally and to articulate social protection networks, aiming to face this issue.
\end{abstract}

Keywords: Bullying. Violence. Adolescent. School health. Descriptive epidemiology. Population surveys.

' Department Of Non-Communicable Diseases Surveillance and Health Promotion, Ministry of Health, Health Surveillance Secretariat - Brasília (DF), Brazil.

"Universidade Federal de Minas Gerais, Brazil - Belo Horizonte (MG), Brazil.

"'Brazilian Institute of Geography and Statistics - Rio de Janeiro (RJ), Brazil.

vNursing School of Ribeirão Preto, Universidade de São Paulo - Ribeirão Preto (SP), Brazil.

vMedical School of Ribeirão Preto, Universidade de São Paulo - Ribeirão Preto (SP), Brazil.

Corresponding author: Deborah Carvalho Malta. Departamento de Vigilância de Doenças e Agravos Não-Transmissíveis e Promoção da Saúde, Secretaria de Vigilância em Saúde, Ministério da Saúde. SAF Sul, Trecho 02, Lotes 05 e 06 , Bloco F, Torre I, Edifício Premium, Térreo, Sala 14, CEP: 70070-600, Brasília, DF, Brasil. E-mail: deborah.malta@saude.gov.br

Conflict of interests: nothing to declare - Financing source: none. 
RESUMO: Objetivo: Descrever a vitimização e a prática de bullying em escolares brasileiros, segundo dados da Pesquisa Nacional de Saúde do Escolar (PeNSE), e comparar a evolução entre as pesquisas de 2009 e 2012. Métodos: Trata-se de estudo transversal com análises univariadas e multivariadas das variáveis: não ser bem tratado, sofrer bullying e praticar bullying. Como variáveis independentes, foram analisadas: idade, sexo, raça/cor, tipo de escola, escolaridade materna. Foram comparadas as prevalências entre as edições da PeNSE de 2009 e 2012. Resultados: Não foram bem tratados pelos colegas na escola $27,5 \%$ dos adolescentes, tendo sido maior a frequência entre meninos $(O R=1,50)$ mais velhos, 15 anos $(O R=1,29)$ e 16 anos $(O R=1,41)$, alunos de escolas públicas $(\mathrm{OR}=2,08)$, de raça/cor preta $(\mathrm{OR}=1,18)$ e cujas mães tinham menor escolaridade. Relatam ter sofrido bullying $7,2 \%$, tendo sido a maior chance em alunos mais jovens (13 anos) do sexo masculino $(\mathrm{OR}=1,26)$, da raça/cor preta $(\mathrm{OR}=1,15)$ e indígena $(\mathrm{OR}=1,16)$ e cujas mães apresentaram menor escolaridade. A prática de bullying foi relatada por $20,8 \%$ e mostrou maior chance em alunos mais velhos, 14 anos $(\mathrm{OR}=1,08)$ e 15 anos $(O R=1,18)$, do sexo masculino $(O R=1,87)$, raça $/$ cor preta $(O R=1,14)$ e amarela $(O R=1,15)$, filhos de mães com maior escolaridade e alunos de escola privada. Ocorreu aumento de bullying nas capitais, passando de 5,4 para 6,8\% entre 2009 e 2012. Discussão: A ocorrência de bullying revela que o contexto escolar brasileiro também tem se tornado um espaço de reprodução da violência, sendo fundamental atuar de forma intersetorial e articulando redes de proteção social, visando seu enfrentamento.

Palavras-chave: Bullying. Violência. Adolescência. Saúde escolar. Epidemiologia descritiva. Inquéritos poupulacionais.

\section{INTRODUCTION}

The World Health Organization defines violence as "the use of physical force or of the real power, or as threats, against oneself, against somebody else, or against a group or a community, which results or can possibly result in lesion, death, psychological damage, deficient development or privacy"1. Violence is a multicausal phenomenon that is strongly associated with economical and sociocultural inequalities; however, it is also related with subjective and behavioral aspects ${ }^{2-4}$.

In Brazil, violence gained major importance due to its magnitude, severity, social impact and ability to make victims and their families vulnerable. Children, adolescents and teenagers are among the most victimized population groups by violence ${ }^{5}$.

There are several types of violence involving children and adolescents in society. Among them, intrafamily violence, school violence and violence in the community stand out ${ }^{6}$. One of the forms of school violence is the aggressive behavior among students, known as bullying. This is a frequent phenomenon involving repeated and intentional acts of oppression, 
humiliation, discrimination, tyranny, aggression and domination of people or groups over other people or groups, who are subjugated by the force of the former ${ }^{7,8}$.

The term bullying comes from the English word bully, which can mean the adjectives "tough guy", "tyrant", or the verbs "brutalize", "tyrannize", "frighten". Therefore, it comprehends a subgroup of aggressive behaviors, characterized by its repetitive nature and power imbalance ${ }^{9}$.

Despite being mostly analyzed in the school context, the practice of bullying surrounds several other spaces and age groups. This practice has been identified in three ways:

1) Direct and physical - including physical aggression, stealing or ruining objects, extorting money or threatening to do so, forcing sexual behaviors or threatening to do so, imposing the performance of servile tasks;

2) Direct and verbal - which involves insulting, putting nicknames, "making fun", making racist comments or ones concerning any differences on the other person; and

3) Indirect - which refers to situations of systematic exclusion of a person from the group, gossiping, spreading rumors, threatening to exclude from the group with the objective of being favored, therefore manipulating the social life of the victim ${ }^{7,8}$.

Bullying should not be considered as a normal characteristic of the development of children and adolescents, but instead, as a risk indicator for the adoption of more severe violent behaviors, including weapon possession, frequent aggressions and lesions ${ }^{10}$. The experience of bullying exposes children and adolescents to the condition of vulnerability ${ }^{10}$. Bullying among students is, in general, found in most schools, regardless of the social, cultural and economic characteristics of the students. Studies demonstrate that this is a worldwide problem, which is common for several countries and schools ${ }^{2,11,12}$.

The exposure to bullying may lead to behavioral and emotional issues, especially stress, decreasing or lost self-esteem, anxiety, depression, poor school performance, and, in more severe cases, even suicide ${ }^{13,14}$.

Some studies have also analyzed the characteristics of the person who performs bullying. In some situations, the same person who practices bullying can be the victim, therefore inverting the roles ${ }^{15}$. Studies including the analysis of the author of the aggression are still scarce in the country. Understanding the forms with which violence presents itself in the school environment is a challenge to face this problem.

In Brazil, the National Adolescent School-based Health Survey (PeNSE), which monitors the health of Brazilian students, included themes about risk and protective factors among adolescents, such as diet, physical activities, intake of substances, violence, and bullying, among others, in its first edition, in $2009^{4}$. In the second edition, PeNSE 2012 amplified the questionnaire and the sample, in order to represent Brazil and its regions, besides introducing new themes, including ones about the practice of bullying ${ }^{16}$.

This study aims at describing the victimization and the practice of bullying among Brazilian students, according to data from PeNSE, and at comparing the evolution between both editions. 


\section{METHODS}

It is a cross-sectional study that analyzed data from the National Adolescent Schoolbased Health Survey (PeNSE), conducted by IBEG together with the Ministry of Health. Ninth grade students attending public and private schools in Brazil participated in PeNSE, in 2012. Some results were compared with those from PeNSE 2009.

The sample was measured according to the School Census $2011^{17}$, in order to estimate population parameters for Brazil, the five major geographic regions of the country (North, Northeast, Southeast, South and Center-West) and 26 state capitals and the Federal District. Considering $50 \%$ prevalence, a maximum error of $0.03(3 \%)$ is considered in absolute values, as well as a $95 \%$ confidence interval $(95 \% \mathrm{CI})^{16}$.

Each of the capitals was defined as a geographic stratum. The other cities, which are not capitals, were grouped inside each of the five major regions, thus forming five strata.

In 2012, the sampling size for the study was of $n=132,123$. Out of this total, 110,873 were present on the day of the study (84\%), and the final number of participants was of $\mathrm{n}=109,104(83 \%)$ students, which corresponded to a general non-response rate of $17 \%$. Sampling weights were used for responding students, in order to represent students enrolled in the $9^{\text {th }}$ grade of elementary school.

According to published data ${ }^{16}$, in the sample of students analyzed in $2012,86 \%$ were aged between 13 and 15 years old; $47 \%$ were male participants and $52.2 \%$ were female participants; $36.8 \%$ were white, $13.4 \%$ were black, $42.2 \%$ were mulattos, $4.1 \%$ were yellow and $3.5 \%$ were indigenous; $17.2 \%$ of the students attended private schools, and $82.8 \%$ of them attended public schools. This distribution is similar to the real population of students.

The self-applicable structured questionnaire was inserted in the smartphone and approaches themes such as diet, physical activity, accidents, violence, mental health, sexuality, among others. This was the second edition of PeNSE and, in 2012, new questions were introduced, including about the practice of bullying. More details about the research can be obtained in other publications ${ }^{16}$.

In this article, violent situations involving adolescents and the following variables were investigated:

- Not being treated well by the colleagues - In the past 30 days, how often did your school colleagues treat you well and/ or were thoughtful to you? Aggregated into: "I was not well treated (not once, rarely)", and "Yes, I was well treated (sometimes, most of the time, always)";

- Suffering bullying - In the past 30 days, how often did any of your colleagues bring you down, made fun of you, mock you? Aggregated into: "Yes (almost always, always)" and "No (rarely, sometimes)";

- Practice bullying - In the past 30 days, did you bring down, mock, intimate or tease any of your school colleagues, so that the person was hurt, annoyed, offended or humiliated? Aggregated into: "Yes" and "No". 
At first, the calculation of the prevalence of these variables and its respective $95 \% \mathrm{CI}$ was conducted with regard to sex, age, race/color, administrative dependency of the school (public or private) and maternal schooling. Univariate and multivariate analyses were also conducted, that is, the estimated crude and adjusted odds ratio (OR) by age, sex, race/color, administrative dependency of the school and maternal schooling. When OR is superior to 1 , it indicates more chances, and inferior to 1 , it indicates protection. If the $95 \%$ CI does not contain the number 1 , then the higher chances or more protection are statistically significant.

The prevalence registered by the variable suffering bullying in the editions of PeNSE 2009 and 2012 was compared for the strata of 26 capitals and the federal district. The sample size for the study of the capitals in 2009 was composed of 60,973 students, and, in 2012, of 61,145 students. The prevalence of the variables per each capital and the $95 \% \mathrm{CI}$ was calculated to verify if there were differences between 2009 and 2012. The collected data were inserted in a data base, being analyzed with the statistical software SPSS (PASW Statistics, version 18).

The study was approved by the Research Ethics Committee of the Ministry of Health, report n. 192/2012, concerning registration n. 16805 of CONEP/MS, on 27/03/2012. Students participated voluntarily. They were aware they were free to not participate, or do not answer part or the whole questionnaire. All of the data of the students, as well as the schools', were kept in secrecy.

\section{RESULTS}

Table 1 describes the sample of students according to the following outcomes: not being well treated, suffering bullying and practicing bullying, and according to the following independent variables: sex, age, color/race, administrative dependency of the school and maternal schooling.

Among $9^{\text {th }}$ grade students, in $2012,27.5 \%(95 \%$ CI $26-29)$ reported that they have bever, or hardly ever, been treated well by the school colleagues, especially among boys, $31.7 \%$ (95\%CI 29.4-34.1); 30.1\% (95\%CI $28.9-31.4)$, in students attending public schools, versus $14.8 \%(95 \%$ CI $13.6-16.1)$ in students attending private schools; black race/color, $31.9 \%$ (95\%CI 29.8 - 31.4) and whose mothers have no schooling, 39.8\% (95\%CI 36.9-42.9) and other mothers with lower schooling. Suffering bullying (always or almost always feeling humiliated) by school colleagues was reported by $7.2 \%(96 \% \mathrm{CI} 6.6-7.8)$ of the students. Percentages were higher among male students, $7.9 \%$ (95\%CI $7.0-9.1)$ versus the female students, $6.5 \%$ (95\% CI $6.2-6.7)$; and among students whose mothers have no schooling, $8.3 \%$ (95\%CI $7.2-9.4)$. The practice of bullying has been reported by $20.8 \%$ of the students (95\%CI 19.5 - 22.2), being more frequent among male participants, $26.1 \%$ (95\%CI $24.5-27.9)$, in relation to female participants, $16.0 \%$ (95\%CI 15.1 - 16.9); and among children whose mothers have higher schooling (Table 1). 
The adjusted OR of not being well treated by school colleagues is higher among older students, aged $15(\mathrm{OR}=1.29)$ and 16 years old $(\mathrm{OR}=1.41)$; male students $(\mathrm{OR}=1.5)$; black race $/$ color $(\mathrm{OR}=1.18)$, and coming from public schools $(\mathrm{OR}=2.08)$. Higher maternal schooling was considered as a protective factor (Table 2).

The adjusted OR shows that the chances of suffering bullying are higher among students aged more than 13 years old. Age is a protective factor against suffering bullying: 16 years old and more $(\mathrm{OR}=0.73) ; 15$ years old $(\mathrm{OR}=0.76) ; 14$ years old $(\mathrm{OR}=0.88)$. The chance of suffering bullying increases among male students $(\mathrm{OR}=1.26)$; mulattos $(\mathrm{OR}-1.15)$ and

Table 1. Prevalence, with a $95 \%$ confidence interval, of having been treated badly, having been bullied and having bullied other children in Brazilian $9^{\text {th }}$ graders, according to age, gender, ethnicity/race and maternal education. Brazil, 2012.

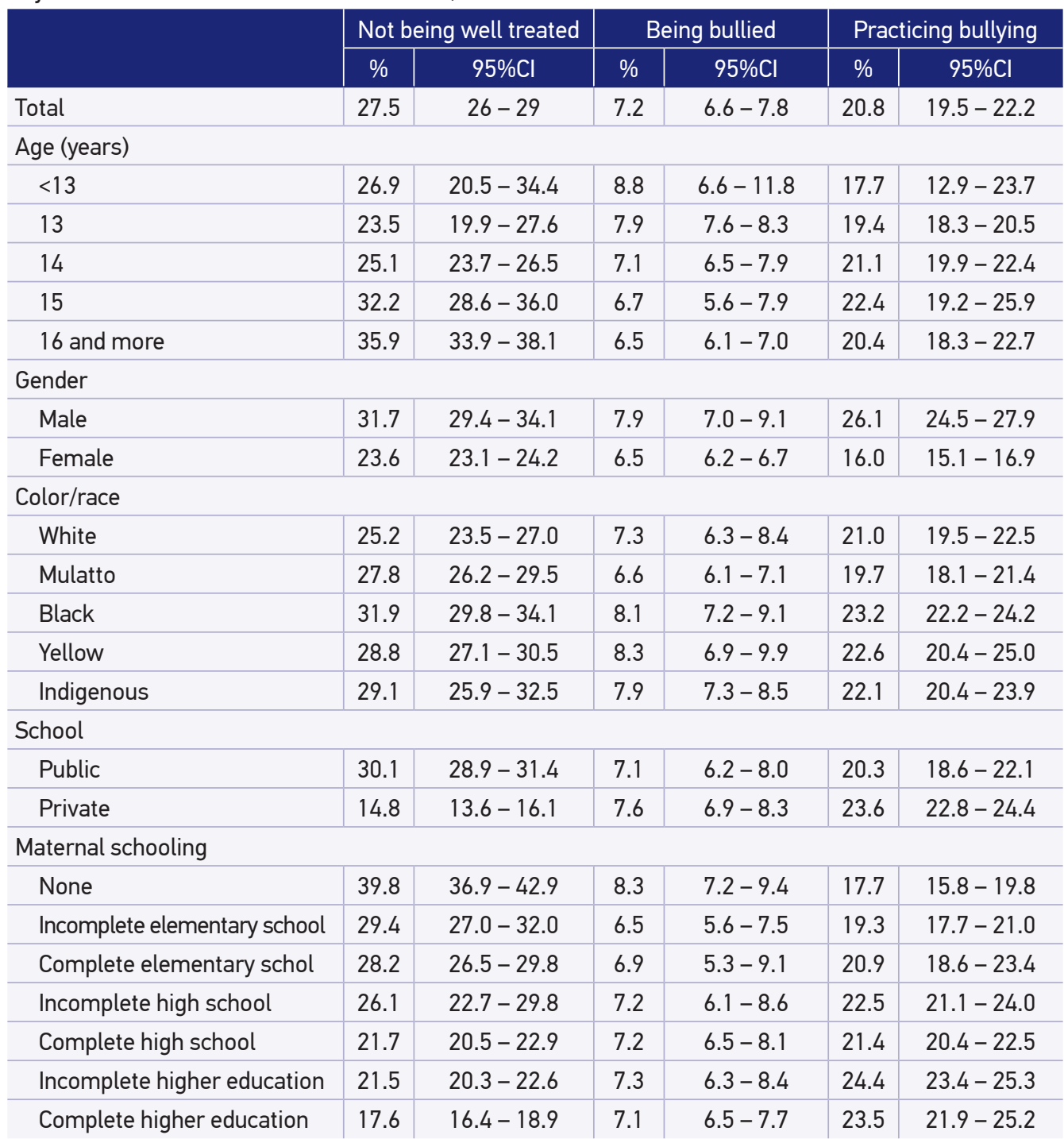


Table 2. Crude and adjusted odds ratio of having been treated badly, having been bullied and having bullied other children in Brazilian 9th graders, according to age, sex, ethnicity/race and maternal education. Brazil, 2012.

\begin{tabular}{|c|c|c|c|c|c|c|c|c|c|c|c|c|}
\hline & \multicolumn{2}{|c|}{ Not being well treated } & \multicolumn{2}{|c|}{ Not being well treated } & \multicolumn{2}{|c|}{ Being bullied } & \multicolumn{2}{|c|}{ Being bullied } & \multicolumn{2}{|c|}{ Practicing bullying } & \multicolumn{2}{|c|}{ Practicing bullying } \\
\hline & \multirow{2}{*}{\begin{tabular}{|c|} 
Crude OR \\
$\%$ \\
\end{tabular}} & \multirow[t]{2}{*}{$95 \% \mathrm{Cl}$} & $\begin{array}{c}\text { Adjusted } \\
\text { OR }^{*}\end{array}$ & \multirow[t]{2}{*}{$95 \% \mathrm{Cl}$} & Crude OR & \multirow{2}{*}{$95 \% \mathrm{Cl}$} & $\begin{array}{c}\text { Adjusted } \\
\mathrm{OR}^{*}\end{array}$ & \multirow{2}{*}{$95 \% \mathrm{Cl}$} & Crude OR & \multirow{2}{*}{$95 \% \mathrm{Cl}$} & $\begin{array}{c}\text { Adjusted } \\
\mathrm{OR}^{*}\end{array}$ & \multirow{2}{*}{$95 \% \mathrm{Cl}$} \\
\hline & & & $\%$ & & $\%$ & & $\%$ & & $\%$ & & $\%$ & \\
\hline \multicolumn{13}{|l|}{ Age (years) } \\
\hline$<13$ & 1.19 & $1.00-1.42$ & 1.15 & $0.92-1.42$ & 1.12 & $0.79-1.58$ & 1.29 & $0.98-1.68$ & 0.89 & $0.64-1.24$ & 0.96 & $0.68-1.360$ \\
\hline 13 & Ref & ref & ref & ref & ref & ref & ref & ref & ref & ref & ref & ref \\
\hline 14 & 1.08 & $0.92-1.27$ & 1.02 & $0.90-1.16$ & 0.89 & $0.80-0.98$ & 0.88 & $0.83-0.93$ & 1.11 & $1.08-1.15$ & 1.08 & $1.03-1.130$ \\
\hline 15 & 1.54 & $1.45-1.63$ & 1.29 & $1.22-1.36$ & 0.83 & $0.69-0.99$ & 0.76 & $0.65-0.88$ & 1.20 & $1.05-1.36$ & 1.18 & $1.08-1.290$ \\
\hline 16 and more & 1.82 & $1.59-2.09$ & 1.41 & $1.22-1.63$ & 0.80 & $0.73-0.87$ & 0.73 & $0.61-0.87$ & 1.06 & $0.91-1.24$ & 1.03 & $0.88-1.200$ \\
\hline \multicolumn{13}{|l|}{ Sex } \\
\hline Male & 1.49 & $1.38-1.62$ & 1.50 & $1.36-1.67$ & 1.24 & $1.10-1.41$ & 1.26 & $1.06-1.51$ & 1.86 & $1.72-2.00$ & 1.87 & $1.67-2.10$ \\
\hline Female & Ref & ref & ref & ref & ref & ref & ref & ref & ref & ref & ref & ref \\
\hline \multicolumn{13}{|l|}{ Color/race } \\
\hline White & Ref & ref & ref & ref & ref & ref & ref & ref & ref & ref & ref & ref \\
\hline Mulatto & 1.14 & $1.10-1.17$ & 1.01 & $0.96-1.05$ & 0.90 & $0.80-1.00$ & 0.92 & $0.81-1.05$ & 0.92 & $0.87-0.97$ & 0.99 & $0.94-1.04$ \\
\hline Black & 1.39 & $1.33-1.45$ & 1.18 & $1.09-1.29$ & 1.12 & $1.04-1.20$ & 1.15 & $1.00-1.33$ & 1.13 & $1.06-1.20$ & 1.14 & $1.06-1.23$ \\
\hline Yellow & 1.20 & $1.09-1.31$ & 1.15 & $0.95-1.33$ & 1.15 & $0.83-1.59$ & 1.27 & $0.86-1.88$ & 1.10 & $1.03-1.17$ & 1.15 & $1.07-1.23$ \\
\hline Indigenous & 1.21 & $1.10-1.34$ & 1.14 & $0.99-1.32$ & 1.08 & $0.89-1.31$ & 1.16 & $1.02-1.32$ & 1.06 & $0.92-1.23$ & 1.03 & $0.93-1.14$ \\
\hline \multicolumn{13}{|l|}{ School } \\
\hline Public & 2.48 & $2.15-2.87$ & 2.08 & $1.97-2.19$ & 0.92 & $0.73-1.16$ & 0.97 & $0.81-1.16$ & 0.82 & $0.73-0.92$ & 0.87 & $0.78-0.97$ \\
\hline Private & Ref & ref & ref & ref & ref & ref & ref & ref & ref & ref & ref & ref \\
\hline \multicolumn{13}{|l|}{ Maternal schooling } \\
\hline None & Ref & ref & ref & ref & ref & ref & ref & ref & ref & ref & ref & ref \\
\hline Incomplete elementary school & 0.63 & $0.59-0.66$ & 0.67 & $0.63-0.72$ & 0.77 & $0.64-0.92$ & 0.75 & $0.64-0.87$ & 1.10 & $1.05-1.16$ & 1.14 & $1.07-1.14$ \\
\hline Complete elementary schol & 0.59 & $0.54-0.64$ & 0.65 & $0.58-0.73$ & 0.82 & $0.63-1.07$ & 0.78 & $0.61-0.99$ & 1.22 & $1.05-1.42$ & 1.19 & $1.06-1.34$ \\
\hline Incomplete high school & 0.533 & $0.48-0.58$ & 0.61 & $0.56-0.65$ & 0.86 & $0.69-1.07$ & 0.81 & $0.67-0.99$ & 1.34 & $1.15-1.56$ & 1.32 & $1.18-1.47$ \\
\hline Complete high school & 0.41 & $0.36-0.47$ & 0.50 & $0.42-0.60$ & 0.86 & $0.70-1.05$ & 0.80 & $0.67-0.95$ & 1.26 & $1.10-1.44$ & 1.22 & $1.11-1.33$ \\
\hline Incomplete higher education & 0.41 & $0.35-0.48$ & 0.55 & $0.44-0.69$ & 0.87 & $0.72-1.04$ & 0.79 & $0.66-0.94$ & 1.49 & $1.32-1.68$ & 1.38 & $1.27-1.50$ \\
\hline Complete higher education & 0.32 & $0.26-0.39$ & 0.49 & $0.39-0.62$ & 0.84 & $0.68-1.04$ & 0.74 & $0.62-0.90$ & 1.42 & $1.19-1.69$ & 1.30 & $1.15-1.47$ \\
\hline
\end{tabular}

*Adjusted for age, sex, race, school (public and private), and maternal education. 
indigenous people $(\mathrm{OR}=1.16)$. The school did not show significant differences, and higher maternal schooling proved to be a protective factor (Table 2).

The practice of bullying, after adjustment by age, sex, race/color, administrative dependency of the school and maternal schooling, on the other hand, was more likely to happen among older students, aged 14 years old or more $(\mathrm{OR}=1.08)$ and 15 years old $(\mathrm{OR}=1.18)$; among male students $(\mathrm{OR}=1.87)$; black $(\mathrm{OR}=1.14)$ and yellow race/ color $(\mathrm{OR}=1.15)$. Students attending public schools practiced less bullying $(\mathrm{OR}=0.87)$, and higher maternal schooling was associated with the more frequent practice of bullying: incomplete higher education ( $\mathrm{OR}=1.38)$, complete higher education $(\mathrm{OR}=1.30)$ and incomplete high school $(\mathrm{OR}=1.32)$ (Table 2).

After analyzing only the set of capitals, the report of suffering bullying increased from 2009 to 2012 among $9^{\text {th }}$ grade students in Brazilian capitals: from 5.4\% (95\%CI $5.1-5.7$ ) to $6.8 \%(95 \% \mathrm{CI} 6.4-7.2)$. The following capitals presented statistically significant increase

Table 3. Prevalence of having been bullied, with a 95\% confidence interval, in Brazilian $9^{\text {th }}$ grade students, according to Brazilian State Capitals and the Federal District. National Adolescent School-based Health Survey, 2009 and 2012.

\begin{tabular}{l|l|l|l|l}
\hline \multirow{2}{*}{ Capital } & \multicolumn{2}{|l|}{2009} & \multicolumn{2}{l}{2012} \\
\hline Porto Velho & $\%$ & $95 \% \mathrm{Cl}$ & $\%$ & $95 \% \mathrm{Cl}$ \\
\hline Rio Branco & 4.1 & $3.2-5.0$ & 5.1 & $4.1-6.3$ \\
\hline Manaus & 5.8 & $4.6-6.9$ & 8.2 & $6.3-10.4$ \\
\hline Boa Vista & 4.8 & $3.7-6.0$ & 5.0 & $4.0-6.2$ \\
\hline Belém & 6.5 & $5.3-7.7$ & 6.8 & $5.7-7.9$ \\
\hline Macapá & 4.2 & $3.3-5.1$ & 4.7 & $3.9-5.6$ \\
\hline Palmas & 4.5 & $3.6-5.4$ & 6.4 & $5.4-7.4$ \\
\hline São Luis & 3.5 & $2.6-4.5$ & 6.6 & $5.4-8.0$ \\
\hline Teresina & 4.8 & $3.9-5.6$ & 5.3 & $4.5-6.3$ \\
\hline Fortaleza & 4.8 & $3.9-5.7$ & 5.0 & $4.1-6.0$ \\
\hline Natal & 4.8 & $3.8-5.9$ & 6.4 & $5.4-7.6$ \\
\hline João Pessoa & 4.2 & $3.3-5.1$ & 6.4 & $5.1-7.9$ \\
\hline Recife & 5.5 & $4.5-6.6$ & 6.2 & $5.2-7.4$ \\
\hline Maceió & 5.7 & $4.7-6.7$ & 6.9 & $6.0-7.9$ \\
\hline Aracaju & 5.3 & $4.0-6.5$ & 5.1 & $4.2-6.1$ \\
\hline Salvador & 4.6 & $3.7-5.6$ & 5.6 & $4.6-6.7$ \\
\hline Belo Horizonte & 4.2 & $3.2-5.1$ & 6.9 & $5.7-8.2$ \\
\hline Vitória & 6.9 & $5.9-7.9$ & 7.6 & $6.5-8.8$ \\
\hline Rio de Janeiro & 5.6 & $4.5-6.6$ & 8.1 & $6.8-9.6$ \\
\hline São Paulo & 5.6 & $4.7-6.5$ & 6.2 & $5.1-7.4$ \\
\hline Curitiba & 5.6 & $4.7-6.6$ & 8.0 & $6.8-9.3$ \\
\hline Florianópolis & 5.7 & $4.7-6.7$ & 7.1 & $5.8-8.6$ \\
\hline Porto Alegre & 4.5 & $3.6-5.4$ & 4.9 & $4.1-5.9$ \\
\hline Campo Grande & 4.7 & $3.6-5.8$ & 4.9 & $3.8-6.2$ \\
\hline Cuiabá & 5.4 & $4.3-6.4$ & 7.2 & $6.1-8.5$ \\
\hline Goiânia & 4.4 & $3.4-5.3$ & 6.1 & $4.8-7.8$ \\
\hline Distrito Federal & 5.6 & $4.7-6.5$ & 6.9 & $6.0-7.9$ \\
\hline Total & 6.5 & $5.5-7.4$ & 7.0 & $6.0-8.3$ \\
\hline & 5.4 & $5.1-5.7$ & 6.8 & $6.4-7.2$ \\
\hline
\end{tabular}


in the period: Vitória, São Paulo, Rio Branco, Salvador, Natal, Macapá, Palmas, Campo Grande, Cuiabá (Table 3).

Not being well treated was more frequent in the North region $(30.7 \%$; $95 \%$ CI $28.5-33.0)$ and less frequent in the South $(25.9 \%$; 95\%CI 23.5 - 28.4); suffering bullying was more prevalent in the South region $(8.2 \%$; $95 \%$ CI $8.0-8.4)$ and less common in the North $(5.7 \%$; $95 \%$ CI $4.0-7.3)$; the practice of bullying was more common in the Southeast and the South regions, respectively (23.6\%; 95\%CI $20.9-26.4$ and 23.2\%; 95\%CI $21.7-24.8)$, and less frequent in the North and Northeast regions (16.5\%; 95\%CI $16.0-17$ and $16.1 \%$; 95\%CI $13.5-18.6$, respectively) (Figure 1 ).

\section{DISCUSSION}

The study points out that about one quarter of the students reported not having been well treated by the colleagues, and this frequency is higher among boys, older and black students of public schools whose mothers had lower schooling. Suffering bullying was prevalent among younger, black and indigenous boys, whose mothers had lower schooling, being more frequent in the South region and less common in the North region. The practice of bullying was reported by one fifth of the students, especially among older, black and yellow race/ color boys, sons of mothers with higher schooling, from private schools, being more frequent in the Southeast and South regions, and

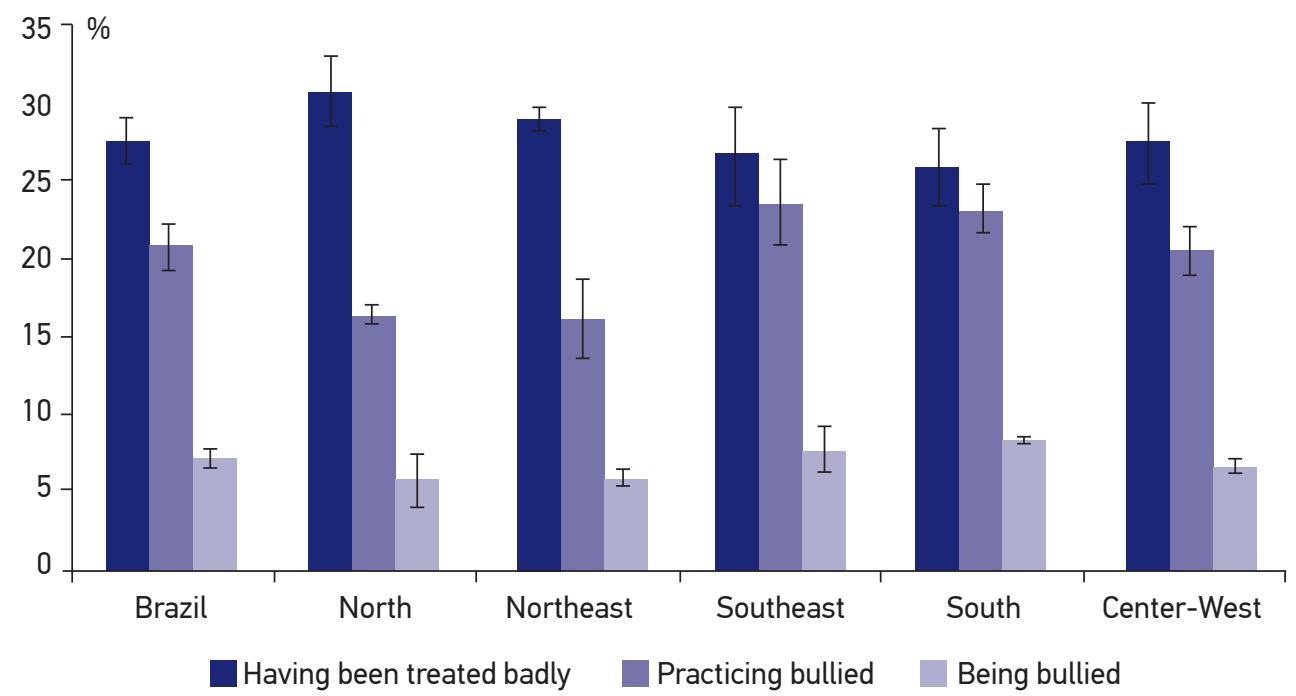

Figure 1. Prevalence, with a 95\% confidence interval, of having been treated badly, having been bullied and having bullied other children in Brazilian $9^{\text {th }}$ graders, according to region. Brazil, 2012. 
less frequent in the North and the Northeast. There was more bullying in the capitals between 2009 and 2012 .

Studies about school violence have been gaining importance for educators, the society and families. School violence refers to a complex phenomenon that has affected the routine, being a daily threat to physical and psychological integrity, as well as to human dignity ${ }^{7,18}$.

Being an aggressor or a victim of bullying is not a school problem to be minimized. On the contrary, this problem may lead to serious consequences, both for the victims and the aggressors, such as depression, for instance, for victims, and criminality or antisocial behavior for aggressors, even during adulthood ${ }^{19}$. Studies prove that children and adolescents who were involved in bullying situations at school in the role of the aggressors were involved in criminality, including violent crimes, in youth and adulthood ${ }^{19}$.

The prevalence of bullying ranges according to the country and regions. A study conducted in the United States with 15,503 students, in 158 schools, showed that $20.1 \%$ of the students were victims of bullying in school in the 12 months prior to the study, being more common among girls $(22 \%)$ than boys $(18.2 \%)^{20}$. In a study with adolescents in European and other developed countries, the World Health Organization identified bullying in $14 \%$ of the 13 year-old adolescents, even though there are great variations between countries ${ }^{12}$.

In Brazil, in 2010, a study with a sample of 5,168 students from the fifth to the eighth grades in public and private schools from the five regions of the country characterized bullying with aggression more frequently and identified $12.5 \%$ of victims ${ }^{18}$.

In national and international studies, it is possible to observed that the event is still prevalent among boys, be it as victims or aggressors and this fact is in accordance with findings in literature ${ }^{12,15,21}$, as well as in PeNSE $2009^{2}$. A recent study conducted in Brazil indicated that boys presented more than twice as many chances of being aggressors in relation to girls in situations involving bullying in school ${ }^{21}$. In the United States, a study describes more prevalence among girls ${ }^{22}$.

The results in this study showed that older students, even from the $9^{\text {th }}$ grade, suffer less bullying, which has also been found in other studies ${ }^{18,23}$. Older students have other characteristics, and they can be more socially engaged, which would lead them to be more protected from victimization. This still needs to be further investigated ${ }^{18}$. The findings in this study corroborate the ones of other authors, indicating higher prevalence of bullying among younger boys, aged between 11 and 14 years old, being less common in elementary and high school. Concerning aggressors, data are not clear, and can even be diverging ${ }^{24}$. In PeNSE, aggressors were mostly older.

It is worth to mention that PeNSE $2009^{2}$ did not find significant differences between the schooling of the parents of boys who suffered bullying. In this study, both the ones who reported suffering bullying and those who were not well treated by the colleagues had mothers with lower or no schooling. With regard to students who practiced bullying, 
the opposite was observed: their mothers had higher schooling, and this result was found in other studies ${ }^{21,23}$. That is, higher maternal schooling proved to be a protective factor against suffering bullying, which is confirmed by a study that points out that children coming from family contexts with restricted cultural capital, who are little encouraged and followed-up by their parents in their academic tasks, and whose parents do not talk or share ideas with them, have higher chances at bullying ${ }^{25}$. It is confirmed, therefore, that the role of parents and family groups should also be valued in investigations and interventions about development, maintenance and prevention of bullying ${ }^{26,27}$.

Scientific evidence shows that the reduced individual and social vulnerability, including the involvement with school violence, is a result of the implementation of the strategy of Health Promoting Schools in a participative educational context. Interdisciplinary, intersectorial and continuous approaches are more effective. A global approach, in which there is coherence between school policies and practices and the promotion of social inclusion and commitment towards education, facilitates the acquirement of better learning results, increases emotional well-being and reduces risk behaviors ${ }^{28}$.

These data corroborate with the statement of recent studies, which have indicated ethnical-racial characteristics as a risk marker for specific health conditions ${ }^{29}$. In the United States, a study identified that African-American studies had $46 \%$ more chances of being a victim in school in relation to white students ${ }^{20}$. Among the causes that motivate bullying, it is possible to mention intolerance against black people, Asians and homosexuals in public schools and against those who do not fit the aesthetic pattern of height/weight and consumption in private schools ${ }^{1}$.

In this sense, it is important to think about the role and the interference of different socialization contexts, such as family, school and society, in the emergence of aggressive behaviors. Dominant social models in a globalized society based on a neoliberal economy have contributed with the increasing rates of systematic intimidation and school victimization $^{30}$.

In Brazil, the National Adolescent School-Based Health Survey (PeNSE), conducted in 2009, enabled to measure the occurrence of bullying among adolescents in schools of Brazilian capitals, thus revealing that the Brazilian school context has also been turning into a space of reproduction of violence ${ }^{2,4}$. PeNSE 2009 indicated that $5.4 \%$ of the students reported having suffered bullying, and this prevalence increased in 2012 . The study pointed out to differences between prevalence in the capitals between 2009 and 2012. In 2012, Rio Branco, São Paulo and Vitória stood out among the capitals with more chances of suffering bullying. Local studies should be conducted to understand these local differences.

This study presents some limitations, which refer to the impossibility of conducting causal inferences between the analyzed outcome and the inclusion of adolescents who were attending school and those who were present in the classroom at the time the questionnaire was applied. This decision may have led to a biased sample, since 
missing school or school evasion may be related to the studied factor. However, this limitation does not nullify the results, since the work was conducted with an expressive sample. Other studies are necessary, especially qualitative analyses, in order to respond to representations, to meanings and senses attributed to bullying by the students and other actors, such as parents and teachers.

Even though some initiatives are expressed as being fragmented and discontinuous, in Brazil there are experiences of public policies and actions that aim at reducing violence and bullying at school, which require an investigative look to assess their pertinence and efficacy. These experiences have happened especially by means of multidisciplinary strategies, the effective participation of different social actors, full care and education in health as instruments of transformation, as well as the empowerment and autonomy of subjects. These programs and instruments have been moving from political federal guidelines, but they also include other actions, which are planned in the scope of each state and in the administrative dynamics and policies of each city ${ }^{9,31-33}$.

\section{CONCLUSION}

The study enabled to identify the occurrence of bullying among adolescents in schools of Brazilian capitals, thus considering observations from other national and international studies. However, the Brazilian school context has also been seen as a space of reproduction of violence.

In this sense, we understand that bullying occurs inside a broad social context, and there are several motivations for it. There are the individual components, that is, the ones related to the group in which students are inserted, and obviously, to families and social and cultural components, which compose the mosaic and the complexities involved in bullying; even though they do not explain it, they give clues about how to intervene in reality efficiently.

In order to stop the (re)production of the bullying cycle in the school context, sociopolitical initiatives in the field should try to answer the challenges to remove this problem from clandestinity. It is important to articulate multiple social sectors and different sectors of society in order to implement public policies that aim at stimulating values and attitudes of peace and healthy relationships. 


\section{REFERENCES}

1. Organização Mundial da Saúde. Health topics: adolescent health [Internet]. Disponível em: http:/ / www.who.int/topics/adolescent_health/en/ (Acessado em 30 de janeiro de 2013).

2. Malta DC, Souza ER, Silva MM, Silva CS, Andreazzi MA, Crespo C, et al. Vivência de violência entre escolares brasileiros: resultados da Pesquisa Nacional de Saúde do Escolar (PeNSE). Ciênc Saúde Coletiva 2010; 15(2): 3053-63.

3. Minayo MC. Violência e Saúde. Rio de Janeiro: Editora Fiocruz; 2006.

4. Brasil. Instituto Brasileiro de Geografia e Estatística. Pesquisa Nacional de Saúde do Escolar 2009. Rio de Janeiro (RJ): IBGE; 2009.

5. Brasil. Secretaria de Vigilância em Saúde. Departamento de Análise de Situação em Saúde. Saúde Brasil 2010: uma análise da situação de saúde. Brasília (DF): Ministério da Saúde; 2011.

6. Malta DC, Mascarenhas MM, Bernal RT, Andrade $S$, Neves A, Melo E, et al. Causas externas em adolescentes: atendimentos em serviços sentinelas de urgência e emergência nas Capitais Brasileiras 2009. Ciênc Saúde Coletiva 2012; 17(9): 2291-304.

7. Pingoelo I, Horiguela ML. Bullying na sala de aula. De Jure (Belo Horizonte) 2010; 15(2): 145-56.

8. Peguero AA. Bullying Victimization and Extracurricular Activity. J School Violence 2008; 7(3): 71-85.

9. Fante C. Fenômeno Bullying: como prevenir a violência nas escolas e educar para a paz. Campinas (SP): Verus Editora; 2005.

10. Nansel TR, Overpeck M, Pilla RS, Ruan WJ, SimonsMorton B, Scheidt P. Bullying behavior among US youth: prevalence and association with psychosocial adjustment. JAMA 2001; 285(16): 2094-100.

11. Carlyle KE, Steinman KJ. Demographic differences in the prevalence, co-occurrence, and correlates of adolescent bullying at school. J Sch Health 2007; 77(9): 623-9.

12. Organização Mundial da Saúde. Inequalities in Young People's Health. Health Behaviour in School-Aged Children. International Report from the 2005/2006 Survey. Copenhagen: WHO; 2008. (Health Policy for Children and Adolescents, no. 5).

13. Jankauskiene R, Kardelis K, Sukys S, Kardeliene L. Associations between school bullying and psychosocial factors. Soc Behav Personal 2008; 36(2): 145-62.

14. Boynton-Jarrett R, Ryan LM, Berkman LF, Wright RJ. Cumulative violence exposure and self-rated health: longitudinal study of adolescents in the United States. Pediatrics. 2008;122(5):961-70.
15. Fleming LC, Jacobsen KH. Bullying among middleschool students in low and middle income countries. Health Promot Int. 2010;25(1):73-84.

16. Brasil. Instituto Brasileiro de Geografia e Estatística. Pesquisa Nacional de Saúde do Escolar 2012. Rio de Janeiro: IBGE, 2013.

17. Brasil. Instituto Nacional de Estudos e Pesquisas Educacionais Anísio Teixeira. Censo Escolar 2011. Brasília: INEP, 2011. Disponível em: http:/ / portal. inep.gov.br/basica-censo (Acessado 26 de outubro de 2013).

18. Fischer RM, Lorenzi GW, Pedreira LS, Bose M, Fante C, Berthoud C, et al. Relatório de pesquisa: bullying escolar no Brasil. Centro de Empreendedorismo Social e Administração em Terceiro Setor (Ceats) e Fundação Instituto de Administração (FIA) [Internet]. 2010. Disponível em: http://catracalivre.folha.uol.com.br/ wp-ontent/uploads/2010/03/Pesquisa-Bullying. pdf (Acessado em 16 de maio de 2010).

19. Ttofi MM, Farrington DP, Lösel F, Loeber R. Do the victims of school bullies tend to become depressed later in life? A systematic review and meta-analysis of longitudinal studies. J Aggress Confl Peace Res 2011; 3(2): 63-73.

20. EUA. Centers for Disease Control and Prevention (CDC). Youth Risk Behavior Surveillance (YRBSS). Morbidity and Mortality Weekly Report. Atlanta: CDC; 2012.

21. Rech RR, Halpern R, Tedesco A, Santos DF. Prevalência e características de vítimas e agressores de bullying. J Pediatr 2013; 89(2): 164-70.

22. Susan L, Wynne SL, Joo HJ. Predictors of School Victimization: Individual, Familial, and School Factors. Crime Delinq 2011; 57(3): 458-88.

23. Silva AP, Ferreira GA, Silva FP, Frazão IS, Cavalcanti AM. Perfil epidemiológico de adolescentes vítimas de bullying em escolas públicas e privadas. Rev Enferm UERJ 2012; 20(2): 808-13.

24. Lopes Neto AA. Bullying: comportamento agressivo entre estudantes. J. Pediatr 2005; 81(5): 164-72.

25. Shetgiri R, Lin H, Avila RM, Flores G. Parental characteristics associated with bullying perpetration in us children aged 10 to 17 years. Am J Public Health 2012; 102(12): 2280-6

26. Pepler D, Jiang D, Craig W, Connolly J. Developmental trajectories of bullying and associated factors. Child Dev 2008; 79(2): 325-38.

27. Sentenac M, Gavin A, Arnaud C, Molcho M, Godeau E, Nic Gabhainn S. Victims of bullying among 
students with a disability or chronic illness and their peers: a cross-national study between Ireland and France. J Adolesc Health 2011; 48(5): 461-6.

28. Young I, Currie C. The HBSC study in Scotland: can the study influence policy and practice in schools? Int J Public Health 2009; 54(2): 271-7

29. Kabad JF, Bastos JL, Santos RV. Raça, cor e etnia em estudos epidemiológicos sobre populações brasileiras: revisão sistemática na base PubMed. Physis 2012; 22(3): 895-918.

30. Barboza GE, Schiamberg LB, Oehmke J, Korzeniewski SJ, Post LA, Heraux CG. Individual characteristics and the multiple contexts of adolescent bullying: an ecological perspective. J Youth Adolesc 2009; 38(1): 101-21.
31. Gonçalves LA, Sposito MP. Iniciativas públicas de redução da violência escolar no Brasil. Cad Pesqui 2006; 115: 101-38.

32. Chrispino A, Dusi ML. Uma proposta de modelagem de política pública para a redução da violência escolar e promoção da Cultura da Paz. Ensaio Aval Pol Públ Educ 2008; 16(61): 597-624.

33. Santos FP, Vidal LM, Bittencourt IS, Boery RN, Sena EL. Estratégias de enfrentamento dos dilemas bioéticos gerados pela violência na escola. Physis 2011; 21(1): 267-81.

Received on: 12/01/2013

Final version presented on: 02/19/2014

Accepted on: 02/21/2014 